Jurnal Ilmu Ilmu Agribisnis: Journal of Agribusiness Science, 9(2), Mei 2021

\title{
PENDAPATAN DAN TINGKAT KESEJAHTERAAN RUMAH TANGGA PETANI UBI KAYU DI KABUPATEN LAMPUNG SELATAN
}

\author{
(The Income and Household Welfare of Cassava Farmers in South Lampung Regency)
}

Grace Lia Ronauli Siahaan, Teguh Endaryanto, Muhammad Ibnu

\author{
Jurusan Agribisnis, Fakultas Pertanian, Universitas Lampung, Jl. Prof. Dr. Soemantri Brojonegoro No.1 \\ Bandar Lampung 35145,e-mail: teguh.endaryanto@fp.unila.ac.id
}

\begin{abstract}
This reseach aims to analyze the condition of cassava agribusiness, household income, and level of household welfare of cassava farmers in South Lampung District. This research is a survey research involving 50 cassava farmers who were selected randomly. Data collection was carried out in May - June 2018. The data analysis method used was a qualitative descriptive approach to determine the condition of the agribusiness system and describe the level of household welfare of cassava farmers and a quantitative descriptive approach to determine the amount of household income of cassava farmers. The study shows that the conditions of the agribusiness system has not been well in several subsystems. The average income of cassava farming is IDR29,458,390.00 per year on land area of 0.65 hectares. Cassava farming contributes 62.34 percent of family income. Using BPS 2014 and Sajogyo (1997) standards, cassava farmers are considered living well.
\end{abstract}

Key words: cassava farming, household, income

\section{PENDAHULUAN}

Perekonomian Provinsi Lampung bertumpu pada sektor pertanian. Sektor pertanian memberikan kontribusi sebesar 40 persen bagi PDRB Provinsi Lampung dan menyediakan lapangan pekerjaan bagi 23,64 persen penduduk. Kondisi ini bertolak belakang dengan keadaan penduduk Provinsi Lampung.

Provinsi Lampung memiliki cukup banyak penduduk miskin yaitu sebesar 1.100.680 jiwa pada tahun 2015 dan meningkat menjadi 1.139.780 jiwa pada tahun 2016 (Badan Pusat Statistik, 2017). Jumlah penduduk miskin di Kabupaten Lampung Selatan terbesar ketiga di Provinsi Lampung setelah Kabupaten Lampung Utara dan Lampung Timur. Kondisi ini bertolak belakang dengan kenyataan bahwa Kabupaten Lampung Selatan memiliki luas lahan yang cukup besar dan menjadi sentral komoditas unggul seperti padi, jagung, pisang, ubi kayu dan sebagainya.

Ubi kayu merupakan salah satu komoditas pangan unggul di Kabupaten Lampung Selatan. Tanaman ubi kayu memiliki luas lahan produksi sebesar 10.398 ha, produksi 258.644 ton dan produktivitas sebesar 24,87 ton/ha. Ubi kayu atau dikenal dengan singkong atau ketela pohon memiliki berbagai macam manfaat. Salah satunya sebagai sumber karbohidrat pengganti beras, bahkan dibeberapa daerah ubi kayu digunakan sebagai makanan pokok.
Kecamatan Natar memiliki luas panen ubi kayu 4.000 ha dan produksi sebesar 95.779 ton dengan produktivitas 23,95 ton/ha. Luas panen dan produksi ubi kayu di Kecamatan Natar mengindikasikan bahwa masyarakatnya mengusahakan tanaman ubi kayu sebagai mata pencaharian (BPS, 2016).

Budidaya tanaman ubi kayu merupakan subsistem dalamsistem agribisnis. Sistem agribisnisadalah kegiatan usaha pertanian dari hulu ke hilir yang terdiri dari subsistem penyediaan sarana produksi, usahatani, pengolahan, pemasaran dan jasa layanan pendukung. Kegiatan-kegiatan pada sistem agribisnis saling berkaitan dan masing-masing kinerja kegiatan akan ditentukan oleh kegiatan lainnya.

Salah satu indikator dalam usaha ubi kayu adalah harga. Harga yang terbentuk mempengaruhi pendapatan yang diperoleh petani. Penurunan harga ubi kayu akan berpengaruh terhadap keberlangsungan usahatani di Kecamatan Natar. Harga yang diterima oleh petani akan mempengaruhi penerimaan usahatani.

Penerimaan usahatani ubi kayu dikurangi jumlah total biaya yang dikeluarkan menghasilkan pendapatan. Biaya produksi akan mempengaruhi pendapatan yang diperoleh petani. Tujuan utama petani dalam kegiatan produksi yaitu memperoleh pendapatan maksimal. Pendapatan tersebut akan 
digunakan kembali sebagai modal dan pemenuhan kebutuhan rumah tangga petani.

Besarnya pendapatan yang diperoleh oleh petani tidak selalu diikuti dengan peningkatan kesejahteraan, karena kesejahteraan juga tergantung pada faktor non-finansial seperti faktor sosial budaya. Penggukuran kesejahteraan dapat ditentukan berdasarkan kemampuan rumah tangga dalam memenuhi kebutuhan pokok dan kebutuhan yang bersifat kebendaan lainnya (Sukirno 2005).

Perkembangan kebutuhan hidup manusia dapat ditentukan oleh tingkat pendapatan rumah tangga petani tersebut. Pendapatan yang cukup dapat dilihat dari tingkat kebutuhan minimum yang diukur dari kebutuhan tiap tahun untuk memenuhi kebutuhan pangan, sandang dan papan dan kebutuhan yang bersifat kebendaan lainnya. Usahatani ubi kayu di Kecamatan Natar memiliki luas panen dan produksi yang cukup besar, sehingga tingkat pendapatan dan pola konsumsi petani dapat menunjukkan tingkat kesejahteraan rumah tangga petani tersebut.

Permasalahan yang diteliti mengenai bagaimana kondisi sistem agribisnis yang berjalan. Sistem agribisnis yang ada dapat mempengaruhi tingkat penerimaan dan pendapatan yang diterima oleh petani. Pendapatan yang dihasilkan akan digunakan untuk memenuhi kebutuhan rumah tangga petani. Kebutuhan yang terpenuhi akan digunakan untuk mengukur tingkat kesejahteraan petani ubi kayu.

Berdasarkan uraian diatas, penelitian ini bertujuan untuk mengetahui kondisi sistem agribisnis dari sisi petani ubi kayu di Kecamatan Natar Kabupaten Lampung Selatan, menganalisis pendapatan rumah tangga petani ubi kayu di Kecamatan Natar Kabupaten Lampung Selatan, dan menganalisis tingkat kesejahteraan rumah tangga ubi kayu di Kecamatan Natar Kabupaten Lampung Selatan.

\section{METODE PENELITIAN}

Penelitian ini dilakukan di Desa Natar dan Desa Muara Putih, Kecamatan Natar Kabupaten Lampung Selatan. Lokasi penelitian ini ditentukan secara sengaja (purposive), dengan pertimbangan bahwa Kecamatan Natar memiliki luas panen dan produksi ubi kayu terbesar di Kabupaten Lampung Selatan. Penelitian dilakukan pada bulan Mei sampai dengan Juni 2018.

Teknik pengambilan sampel dilakukan dengan metode acak sederhana (simple random sampling). Penentuan jumlah sampel menggunakan rujukan teori Sugiarto (2003):

$\eta=\frac{N Z^{2} S^{2}}{N d^{2}+Z^{2} S^{2}}$

Keterangan:

$\mathrm{n} \quad=$ Jumlah sampel

$\mathrm{N}=$ Jumlah populasi

$\mathrm{S}^{2}=$ Variasi sampel $(5 \%=0,05)$

$\mathrm{Z} \quad=$ Tingkat kepercayaan $(90 \%=1,64)$

$\mathrm{d}=$ Derajat penyimpangan $(5 \%=0,05)$

Berdasarkan persamaan satu (1), maka diperoleh jumlah sampel sebanyak 50 petani ubi kayu dari total populasi yang berjumlah 729 petani ubi kayu. Data yang dikumpulkan dalam penelitian ini terdiri dari data primer dan data sekunder. Data primer diperoleh dengan wawancara secara langsung menggunakan kuisoner. Data sekunder diperoleh darin instansi dan literatur yang terkait dengan penelitian.

Metode analisis yang digunakan yaitu analisis deskriptif kualitatif untuk mengetahui subsistem agribisnis (subsistem pengadaan menggunakan kriteria 6 tepat, analisis pendapatan usahatani, tidak meneliti subsistem pengolahan, melihat saluran pemasaran dan melihat jasa layanan pendukung yang ada di daerah penelitian) dan menggambarkan tingkat kesejahteraan rumah tangga petani dan analisis kuantitatif untuk mengetahui besarnya pendapatan usahatani ubi kayu, pendapatan rumah tangga, biaya pengeluaran rumah tangga dan tingkat kesejahteraan rumah tangga petani. Pendapatan dari usaha tani digunakan rumus sebagai berikut :

$\pi=\mathrm{PT}-\mathrm{BT}$

$\pi=$ Y.PY $-\sum_{i=1}^{\mathrm{n}}$ Xi.Pxi - BTT

Keterangan :

$\pi=$ Pendapatan

$\mathrm{Y}=$ Hasil produksi $(\mathrm{kg})$

Py $=$ Harga hasil produksi $(\mathrm{Rp})$

$\mathrm{Xi}=$ Faktor produksi ke-i $\mathrm{i}=1,2,3,4, \mathrm{n}$

Pxi $=$ Harga faktor produksi $\mathrm{k}-\mathrm{i}(\mathrm{Rp} / \mathrm{satuan})$

BTT $=$ Biaya tetap total $(\mathrm{Rp})$

$\mathrm{PT}=$ Penerimaan Total $(\mathrm{Rp})$

$\mathrm{BT}=$ Biaya Total $(\mathrm{Rp})$

Untuk mengetahui usahatani ubi kayu menguntungkan atau tidak secara ekonomi dapat dianalisis dengan menggunakan nisbah atau perbandingan antara penerimaan dengan biaya 
(Revenue Cost Ratio). Secara matematis dapat dirumuskan sebagai berikut:

$\mathrm{R} / \mathrm{C}=\mathrm{PT} / \mathrm{BT}$

Keterangan:

$\mathrm{R} / \mathrm{C}=$ Nisbah penerimaan dan biaya

$\mathrm{PT}=$ Penerimaan Total $(\mathrm{Rp})$

$\mathrm{BT}=$ Biaya Total $(\mathrm{Rp})$

Kriteria pengambilan keputusan adalah sebagai berikut:

(1) Jika $\mathrm{R} / \mathrm{C}>1$, maka usahatani mengalami keuntungan karena penerimaan lebih besar dari biaya.

(2) Jika R/C < 1, maka usahatani mengalami kerugian karena penerimaan lebih kecil dari biaya.

(3) Jika $\mathrm{R} / \mathrm{C}=1$, maka usahatani mengalami impas karena penerimaan sama dengan biaya.

Pendapatan rumah tangga petani dirumuskan sebagai berikut:

Prt $=\underset{\text { Parmfarm }}{1}+$ Ponfarm $_{2}+$ Poff farm + Pnon

Keterangan :

Prt = Pendapatan rumah tangga petaniubi kayu per tahun

Pon-farm f $_{1}=$ Pendapatan dari usahatani ubi kayu

Pon-farm ${ }_{2}$ = Pendapatandari usahatani bukan ubikayu

Poff-farm = Pendapatan bidang pertanian diluar usahatani

Pnon-farm = Pendapatan dari luar pertanian

Badan Pusat Statistik (2014) digunakan untuk mengukur kesejahteraan rumah tangga yang disesuaikan oleh informasi tentang kependudukan, kesehatan dan gizi, pendidikan, ketenagakerjaan, pola konsumsi atau pengeluaran rumah tangga, perumahan dan lingkungan, dan sosial lainnya. Kesejahteraan masyarakat dikelompokan menjadi dua yaitu sejahtera dan belum sejahtera. Masingmasing indikator ditentukan dengan cara mengurangkan jumlah skor tertinggi dengan jumlah skor terendah. Hasil pengurangan dibagi dengan jumlah indikator atau klasifikasi yang digunakan. Rumus penentuan range skor adalah:

$\mathrm{RS}=\frac{\mathrm{SkT}-\mathrm{SkR}}{\mathrm{JKl}}$

Keterangan :

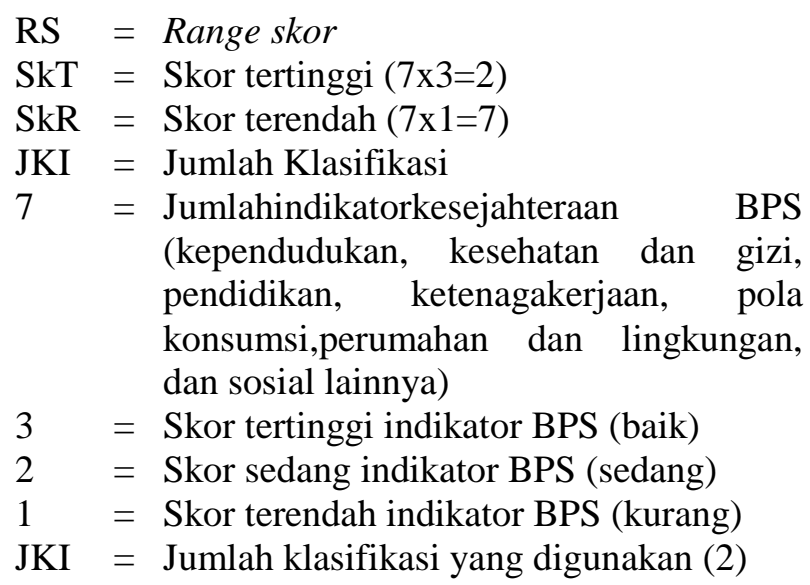
(kependudukan, kesehatan dan gizi, pendidikan, ketenagakerjaan, pola konsumsi,perumahan dan lingkungan, dan sosial lainnya)

$3=$ Skor tertinggi indikator BPS (baik)

$2=$ Skor sedang indikator BPS (sedang)

$1=$ Skor terendah indikator BPS (kurang)

JKI = Jumlah klasifikasi yang digunakan (2)

Hasil perhitungan berdasarkan rumus di atas diperoleh Range Skor (RS sama dengan 7), sehingga dapat dilihat interval skor yang akan menggambarkan tingkat kesejahteraan rumah tangga. Hubungan antara interval skor dan tingkat kesejahteraan adalah :

(1) Skor antara 7-14 berarti rumah tangga petani ubi kayu belum sejahtera.

(2) Skor antara 15-21 berarti rumah tangga petani ubi kayu sejahtera.

Pengukuran tingkat kesejahteraan rumah tangga petani menurut kriteria Sajogyo (1997) dilakukan dengan cara menghitung pengeluaran rumah tangga per kapita per tahun yaitu total pengeluaran rumah tangga petani dalam setahun dibagi jumlah tanggungan rumah tangga. Pengeluaran rumah tangga/kapita pertahun ini kemudian dikonversikan ke dalam ukuran setara beras per kilogram. Pengukuran tingkat kesejahteraan rumah tangga petani digunakan batas garis kemiskinan dengan kriteria sebagai berikut:

(1) Paling miskin : pendapatan per anggota keluarga, $180 \mathrm{~kg}$ setara beras/tahun

(2) Miskin sekali : 181-240 kg setara beras/tahun

(3) Miskin : 241 - $320 \mathrm{~kg}$ setara beras/tahun

(4) Nyaris miskin : 321-480 kg setara beras/tahun

(5) Cukup : 481 - $960 \mathrm{~kg}$ setara beras/tahun

(6) Hidup layak : $>960 \mathrm{~kg}$ setara beras/tahun.

\section{HASIL PEMBAHASAN}

\section{Karakteristik Responden}

Berdasarkan hasil penelitian yang dilakukanumur petani sangat bervariasi mulai dari 30 sampai 70 tahun dengan rata-rata umur 49,05 tahun. Petani berada pada usia produktif yaitu 36 - 55 tahun yang cukup potensial untuk mengelola usahatani dengan baik.

Tingkat pendidikan petani sebesar 60 persen merupakan lulusan SMA. Soekartawi (2002), 
berpendapat bahwa petani berpendidikan akan lebih mudah dalam mengadopsi inovasi, dibandingkan dengan petani yang berpendidikan lebih rendah. Lama usahatani yang dilakukan petani berkisar 6-35 tahun dengan pengalaman rata-rata 20 tahun. Sebesar 40 persen responden memiliki pengalaman usaha selama 16-25 tahun.

Terkait dengan jumlah tanggungan dalam keluarga menunjukkan bahwa petani memiliki tanggungan antara 4-5 orang sebesar 74 persen. Rata-rata luas lahan yang dimiliki petani responden adalah 0,65 ha dengan rentang luasan antara $0,01-0,50$ ha yang menunjukkan bahwa usahatani ubi kayu di Kecamatan Natar masih dalam skala kecil.

Selainusahatani ubi kayu, petani memiliki pekerjaan sampingan untuk menambah pendapatan yang digunakan sebagai pemenuhan biaya rumah tangga sehari-hari. Pekerjaan sampingan yang dilakukan meliputi lingkup pertanian yaitu usahatani komoditas lain, berternak, atau sebagai buruh tani serta diluar lingkup pertanian meliputi pedagang, Pegawai Negeri Sipil (PNS) dan penyewaan jasa (barang dan tempat). Selain itu ada beberapa petani yang memiliki tunjangan berupa dana pensiun. Petani yang memiliki pekerjaan sampingan sebesar 50 persen.

\section{Sistem Agribisnis}

Pengadaan sarana produksi merupakan kegiatan awal yang dilakukan dalam usahatani. Pengadaan sarana produksi yaitu kegiatan penyediaan yang terdiri dari bibit, pupuk, pestisida, alat-alat pertanian dan sebagainya. Pupuk, pestisida dan alat-alat pertanian diperoleh dengan cara pembelian sedangkan bibit diperoleh dengan cara membuat sendiri.

Tabel 1. Pengadaan sarana Produksi berdasarkan kriteria 6 tepat

\begin{tabular}{lcccccc}
\hline $\begin{array}{c}\text { Sarana } \\
\text { Produksi }\end{array}$ & $\begin{array}{c}\text { Tepat } \\
\text { Waktu }\end{array}$ & $\begin{array}{c}\text { Tepat } \\
\text { Tempat }\end{array}$ & $\begin{array}{c}\text { Tepat } \\
\text { Kualitas }\end{array}$ & $\begin{array}{c}\text { Tepat } \\
\text { Kuantitas }\end{array}$ & $\begin{array}{c}\text { Tepat } \\
\text { Jenis }\end{array}$ & $\begin{array}{c}\text { Tepat } \\
\text { Harga }\end{array}$ \\
\hline Bibit & V & V & V & V & V & V \\
Pupuk & X & V & V & X & V & V \\
Pestisida & V & V & V & X & V & V \\
$\begin{array}{l}\text { Peralatan } \\
\text { Pertanian }\end{array}$ & V & V & V & V & V & V \\
Tenaga & V & V & V & V & V & V \\
Kerja & & & & & & \\
\hline Ket: & V = tepat & & X tidak tepat & &
\end{tabular}

Pengadaan sarana produksi berkaitan dengan pemenuhan 6 tepat yaitu tepat waktu, tempat, kualitas, kuantitas, jenis dan harga. Penilaian pengadaan sarana produksi berdasarkan kriteria tepat waktu, tempat, kualitas, kuantitas, jenis dan harga dapat dilihat pada Tabel 1 .

Tabel 1 menunjukkan bahwa kegiatan pengadaan sarana produksi usahatani ubi kayu yang meliputi bibit, peralatan pertanian serta penggunaan tenaga kerja sudah memenuhi kriteria 6 tepat. Akan tetapi dalam pengadaan pupuk dinilai belum memenuhi kriteria tepat waktu dan tepat kuantatis dan pengadaan pestisida belum memenuhi kriteria tepat kuantitas.

Subsistem usahatani merupakan tahap membudidayakan ubi kayu dengan mengalokasikan sumberdaya yang ada secara efisien dan efektif untuk menghasilkan pendapatan yang maksimal. Waktu yang diperlukan dari penanaman hingga pemanenan ubi kayu sekitar 78 bulan, sedangkan untuk keperluan bibit sekitar 10 bulan. Tanam ubi kayu di Kecamatan Natar berlangsung pada bulan Agustus hingga Oktober.

Kegiatan usahatani di daerah penelitian memiliki rata-rata luas lahan sebesar 0,65 ha menggunakan bibit sebanyak 6.500 batang. Penggunaan pupuk pada usahatani yaitu pupuk kandang $169 \mathrm{~kg}$, pupuk phonska $137,50 \mathrm{~kg}$ dan pupuk urea $84,50 \mathrm{~kg}$ dengan biaya pupuk sebesar Rp673.890,00. Penggunaan pestisida pada usahatani yaitu pestisida Rendy 4 liter dan pestisida Indodan 0,86 liter dengan biaya pestisida sebesar Rp148.959,00. Alat pertanian yang digunakan dalam kegiatan usahatani ini antara lain cangkul, koret, arit dan sprayer dengan penyusutan sebesar Rp93.671,64. Tenaga kerja yang digunakan adalah tenaga kerja wanita dan tenaga kerja pria baik dalam keluarga dan luar keluarga. Penggunaan tenaga kerja dalam keluarga 10,46 HOK, luar keluarga 70,11 HOK dan tenaga mesin $3,90 \mathrm{HOK}$.

Subsistem pengolahan merupakan kegiatan pengolah hasil pertanian menjadi produk yang memiliki nilai tambah. Pada penelitian ini petani tidak melakukan kegiatan pengolahan pada ubi kayu yang dihasilkan, petani menjual hasil panennya langsung kepada konsumen, pedagang pengumpul dan/atau langsung menjual ke pabrik untuk diolah menjadi barang jadi. 


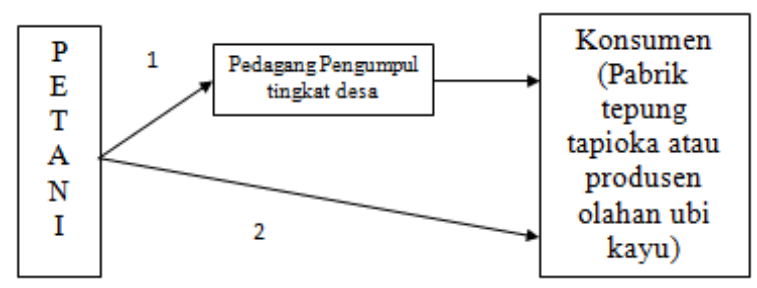

Gambar 1. Saluran pemasaran ubi kayu

Saluran pemasaran adalah serangkaian lembaga yang melakukan semua fungsi yang digunakan untuk menyalurkan produk dan status kepemilikannya dari produsen ke konsumen. Saluran pemasaran yang ada di daerah penelitian terdiri dari dua saluran pemasaran. Sebesar 68 persen petani menggunakan saluran pemasaran 1 dan sebesar 32 persen petani menggunakan saluran pemasaran 2. Saluran pemasaran tersebut dapat dilihat pada Gambar 1.

Subsistem jasa layanan pendukung merupakan kegiatan yang menyediakan jasa pendukung untuk keberlangsungan sistem agribisnis ubi kayu. Jasa layanan pendukung yang ada di daerah penelitian antara lain:

a. Lembaga pendidikan, penyuluhan dan pelatihan seperti Penyuluhan Pertanian, Balai Pelatihan Pertanian, dan Universitas Lampung. Petani belum memanfaatkan adanya penyuluh secara optimal karena penyuluh lebih sering menyuluhan mengenai komoditas padi, jagung dan kedelai.

b. Lembaga pendukung yang bergerak dibidang dana dan permodalan pada penelitian ini yaitu Koperasi Simpan Pinjam (KSP) Tani Makmur, beberapa bank milik negara dan tengkulak. Para petani tidak memanfaatkan jasa koperasi dikarenakan modal sendiri yang cukup untuk usahatani. Bila dalam keadaan terdesak petani lebih memilih meminjam modal kepada tengkulak dengan alasan persyaratan yang lebih mudah dan dalam waktu singkat, selain itu pelunasan dapat dilakukan setelah musim panen.

c. Peraturan pupuk bersubsidi berdasarkan Peraturan Menteri Pertanian Nomor 47/Permentan/SR.310/12/21017 tentang alokasi dan harga eceran tertinggi pupuk bersubsidi untuk sektor pertanian. Selain itu pemerintah mengeluarkan kebijakan berhubungan dengan harga dasar atau harga jual beli yang bertujuan untuk melindungi petani dan konsumen dari kerugian.

d. Sarana tranportasi yang dapat dimanfaatkan oleh petani adalah motor dan mobil pengangkut. Alat transportasi motor digunakan untuk pengadaan sarana produksi dan mobil digunakan untuk pengangkut ke pabrik atau pedagang pengumpul. Selain itu infrastruktur jalan di daerah penelitian cukup baik dan memadai.

e. Keberadaan pasar dekat dengan rumah petani sehingga mudah terjangkau. Pasar belum dimanfaatkan oleh petani untuk menjual hasil panennya.

\section{Pendapatan Usahatani Ubi kayu}

Pendapatan usahatani merupakan selisih antara penerimaan usahatani dengan biaya-biaya produksi, yang menghasilkan tingkat keuntungan usahatani yang diperoleh. Rata-rata penerimaan yang diperoleh petani dari hasil usahatani ubi kayu di daerah penelitian pada lahan seluas 0,65 hektar adalah sebesar Rp34.497.000,00/tahun atau sebesar Rp53.072.307,69/ha/tahun, dengan biaya total produksi sebesar Rp15.434.469,64 per 0,65 ha per tahun atau Rp23.745.337,91/ha. Rata-rata penerimaan, biaya dan pendapatan usahatani ubi kayu di Kecamatan Natar 2018 dapat dilihat pada Tabel 2.

Tabel 2. Rata-rata penerimaan, biaya dan pendapatan usahatani ubi kayu di Kecamatan Natar 2018

\begin{tabular}{lcrr}
\hline \multicolumn{1}{c}{ Uraian } & \multirow{2}{*}{ Satuan } & \multicolumn{2}{c}{ Perhektar } \\
\cline { 3 - 4 } & & \multicolumn{1}{c}{ Fisik } & \multicolumn{1}{c}{ Nilai (Rp) } \\
\hline Penerimaan & & & \\
Produksi & $\mathrm{Kg}$ & $30.049,23$ & $53.072 .307,69$ \\
Biaya tunai & & & \\
Pupuk Kandang & $\mathrm{Kg}$ & 260,00 & $139.138,46$ \\
Pupuk Phonska & $\mathrm{Kg}$ & 211,54 & $621.261,54$ \\
Pupuk Urea & $\mathrm{Kg}$ & 130,00 & $276.353,85$ \\
Rendy & $\mathrm{L}$ & 6,15 & $207.230,77$ \\
Indodan & $\mathrm{L}$ & 1,32 & $27.476,92$ \\
TKLK & $\mathrm{HOK}$ & 113,87 & $6.238 .984,62$ \\
Pajak & $\mathrm{Rp}$ & & $217.353,85$ \\
Transportasi & $\mathrm{Rp}$ & & $23.907,69$ \\
Total BiayaTunai & & & $7.751 .707,69$ \\
Biaya & & & \\
Diperhitungkan & & & \\
Bibit & $\mathrm{Rp}$ & $10.000,00$ & $10.000 .000,00$ \\
Penyusutan & $\mathrm{Rp}$ & & $144.553,30$ \\
Sewa Lahan & $\mathrm{Rp} / \mathrm{ha}$ & & $5.000 .000,00$ \\
TKDK & $\mathrm{HOK}$ & 16,09 & $849.076,92$ \\
Total Biaya & & & \\
Diperhitungkan & & & $15.993 .630,22$ \\
Biaya Total & & & $23.745 .337,91$ \\
$\begin{array}{l}\text { Pendapatan } \\
\text { Biaya Tunai }\end{array}$ & & & $45.320 .600,00$ \\
$\begin{array}{l}\text { Pendapatan } \\
\text { Biaya Total }\end{array}$ & & & \\
R/C Tunai & & & $29.326 .969,78$ \\
R/C Total & & & 6,85 \\
\hline & & & \\
\hline
\end{tabular}


Tabel 2 menunjukkan biaya-biaya produksi yang dikeluarkan oleh petani pada satu kali musim tanam terdiri dari biaya tunai sebesar Rp5.038.610,00 per 0,65 ha dan Rp7.751.707,69 /ha dan untuk total biaya sebesar Rp10.395.859,64 per 0,65 ha dan Rp15.993.630,22/ha. Pendapatan atas biaya tunai usahatani sebesar Rp29.458.390,00 per 0,65 ha per tahun dan Rp45.320.600,00/ha/tahun dan pendapatan atas biaya total sebesar Rp19.062.530,36 per 0,65 ha per tahun dan Rp29.326.969,78/ha/tahun.

Nilai R/C yang diperoleh atas biaya tunai sebesar 6,85 dan atas biaya total sebesar 2,24. Nilai R/C yang diperoleh menunjukkan bahwa penerimaan yang dihasilkan petani lebih besar dibandingkan biaya yang dikeluarkan dan hal tersebut menunjukkan bahwa usahatani ubi kayu layak untuk dijalankan petani di Kecamatan Natar. Hasil penelitian ini berbeda dengan Clinton, Ginting dan Jufri (2015) hal ini dikarenakan perbedaan tempat penelitian, harga jual ubi kayu serta penggunaan sarana produksi.

\section{Pendapatan On Farm}

Mayoritas masyarakat di daerah penelitian sebagian besar adalah petani. Usahatani merupakan mata pencaharian utama di Kecamatan Natar. Pendapatan rumah tangga petani terbesar diperoleh dari pendapatan on farm baik dari usahatani ubi kayu atau komoditas lain maupun peternakan. Total pendapatan usaha on farm adalah sebesar Rp35.432.060,00/tahun. Kontribusi pendapatan on farm terbesar berasal dari pendapatan usahatani ubi kayu yaitu Rp29.458.390,00/tahun.

\section{Pendapatan Off Farm}

Pendapatan rumah tangga petani berasal dari pekerjaan off farm sebagai buruh tani. Petani yang memiliki usaha sebagai buruh tani sebanyak 9 orang. Rata-rata pendapatan off farm rumah tangga petani sebesar Rp1.155.000,00/tahun. Kondisi ini sejalan dengan penelitian Puji, Gitosaputro dan Nikmatullah (2017) yang menyatakan bahwa pendapatan off farm berasal dari buruh tani dan penyewaan traktor, hal ini terjadi karena setiap daerah memiliki perbedaaan potensi.

\section{Pendapatan Non Farm}

Pendapatan rumah tangga petani juga diperoleh dari kegiatan usaha diluar bidang pertanian.
Pendapatan tersebut berasal dari dagang (warung), Pegawai Negeri Sipil (PNS), penyewaan (tempat atau barang) dan dana pensiun. Rata-rata jumlah pendapatan usaha non farm sebesar Rp10.660.080,00/tahun dengan kontribusi terbesar yaitu pedagang sebesar Rp5.284.000,00/tahun. Menurut penelitian Gusti, Haryono dan Prasmatiwi (2013), besarnya kontibusi pendapatan non farm memberikan peranan dalam memenuhi kebutuhan serta menambah aset petani guna mempertahankan hidup.

\section{Pendapatan Rumah Tangga}

Petani memperoleh penghasilan dari usahatani atau budidaya (on farm), usaha di luar kegiatan usahatani (off farm), dan usaha diluar bidang pertanian (non farm). Sumber pendapatan petani dari kegiatan usahatani (on farm) ubi kayu memberikan kontribusi terbesar (62,34 persen) dibandingkan dari sumber pendapatan lain (offfarm dan non farm). Kondisi ini memperlihatkan bahwa petani mengandalkan usahataniubi kayusebagai sumber pendapatan utama mereka di tengah pergeseran tenaga kerja dari sektor pertanian ke sektor lain. Pendapatan rata-rata rumah tangga petani per tahun serta kontribusinya disajikan pada Tabel 3.

Tabel 3 menunjukkan rata-rata total pendapatan rumah tangga petani ubi kayu dari beberapa sumber sebesar Rp47.253.140,00/tahun atau sebesar Rp3.937.761,67/bulan. Total pendapatan yang diterima oleh rumah tangga petani tersebut berada diatas Upah Minimum Provinsi (UMP) Lampung pada tahun 2018 sebesar Rp2.241.269,00/bulan. Pendapatan yang diterima petani digunakan untuk memenuhi kebutuhannya.

Tabel 3. Rata-rata pendapatan rumah tangga petani ubi kayu di Kecamatan Natar, Lampung Selatan, 2018

\begin{tabular}{lcc}
\hline \multicolumn{1}{c}{ Sumber Pendapatan } & Pendapatan (Rp) & Persentase( \%) \\
\hline $\begin{array}{l}\text { On farm } \\
\text { a. Usahatani ubi }\end{array}$ & $29.458 .390,00$ & 62,34 \\
$\quad$ kayu & $4.688 .670,00$ & 9,92 \\
b. Usahatani lainnya & $1.285 .000,00$ & 2,72 \\
c. Usaha ternak & & \\
Off farm & $1.155 .000,00$ & 2,45 \\
a. Buruh tani & & \\
Non Farm & $5.284 .000,00$ & 11,18 \\
a. Pedagang & $1.990 .080,00$ & 4,21 \\
b. Pegawai & $1.592 .000,00$ & 3,37 \\
c. Penyewaan & $1.800 .000,00$ & 3,81 \\
d. Pensiunan & $47.253 .140,00$ & 100,00 \\
\hline Jumlah &
\end{tabular}




\section{Analisis Tingkat Kesejahteraan Rumah Tangga Petani Ubi kayu}

Tingkat kesejahteraan rumah tangga diukur berdasarkan kriteria BPS (2014) dengan pengukuran beberapa indikator, yaitu kependudukan, kesehatan dan gizi, pendidikan, ketenagakerjaan, pola konsumsi, perumahan dan lingkungan, sosial dan lain-lain. Masing-masing indikator dimasukkan dalam kelas-kelas untuk mengetahui keadaannya. Hasil kriteria indikator kesejahteraan BPS (2014) dapat dilihat pada Tabel 4.

Tabel 4 menunjukkan bahwa kategori kependudukan serta perumahan dan lingkung berada dalam kelas baik artinya petani mampu memenuhi kebutuhan rumah tangga baik pangan dan non pangan. Kemudian tingkat kesejahteraan ini dikelompokkan dalam dua kategori yaitu sejahtera dan belum sejahtera. Tingkat kesejahteraan rumah tangga petani ubi kayu di Kecamatan Natar menurut BPS dapat dilihat pada Tabel 5.

Tabel 5 menunjukkan hasil penelitian menunjukkan bahwa 86 persen rumah tangga petani masuk dalam kategori sejahtera dan sebesar 14 persen rumah tangga petani masuk dalam kategori belum sejahtera. Faktor yang menyebabkan rumah tangga petani sejahtera adalah letak lokasi penelitian yang tidak jauh dari pusat pemasaran dan Kota Bandar Lampung yang merupakan pusat pertumbuhan ekonomi sehingga dekat dengan sarana dan prasarana yang mendukung. Hasil penelitian ini juga sejalan dengan penelitian Saputra, Wijaya dan Umi (2016) mengenai pendapatan dan kesejateraan anggota koperasi di Kecamatan Natar dimana petani berada dalam golongan rumah tangga sejahtera.

Tabel 4. Hasil kriteria indikator kesejahteraan BPS (2014)

\begin{tabular}{lccc}
\hline \multicolumn{1}{c}{ Kategori } & \multicolumn{3}{c}{ Kelas } \\
\cline { 2 - 4 } & Baik & Cukup & Kurang \\
\hline Kependudukan & $\sqrt{ }$ & \\
Kesehatan dan Gizi & $\sqrt{ }$ \\
Pendidikan & & $\sqrt{ }$ \\
Ketenagakerjaan & & $\sqrt{ }$ \\
Taraf dan Pola & & & \\
Konsumsi & & \\
Perumahan dan & $\sqrt{ }$ & \\
Lingkungan & & $\sqrt{ }$ \\
Sosial dan lain-lain & & \\
\hline
\end{tabular}

Tabel 5. Sebaran kesejahteraan rumah tangga petani ubi kayu di Kecamatan Natar, Lampung Selatan, 2018

\begin{tabular}{lccc}
\hline \multicolumn{1}{c}{ Kategori } & $\begin{array}{c}\text { Interval } \\
\text { Skor }\end{array}$ & $\begin{array}{c}\text { Jumlah } \\
\text { (orang) }\end{array}$ & Persentase \\
\hline Sejahtera & $15-21$ & 43 & 86,00 \\
Belum sejahtera & $07-14$ & 7 & 14,00 \\
\hline Jumlah & & 50 & 100,00 \\
\hline
\end{tabular}

Menurut Sajogyo (1997), pengeluaran rumah tangga per kapita per tahun adalah total pengeluaran rumah tangga petani baik pengeluaran untuk pangan maupun non pangan dalam satu tahun yang diukur dengan standar harga beras per kilogram. Pengeluaran pangan pada penelitian ini dibedakan atas pengeluaran pangan pokok, umbiumbian, minyak dan lemak, pangan nabati, pangan hewani, kacang-kacangan, sayur-sayuran, buahbuahan, gula, bumbu-bumbuan dan minuman, sedangkan pengeluaran non pangan terdiri dari kesehatan, pendidikan, listrik, alat komunikasi, perabotan dan perbaikan rumah, pakaian dan aksesoris, barang dan jasa, transportasi, bahan bakar, sosial, pajak, dan kebersihan badan. Ratarata pengeluaran rumah tangga petani ubi kayu per tahun di Kecamatan Natar dapat dilihat pada Tabel 6.

Tabel 6 menunjukkan rata-rata pengeluaran rumah tangga petani sebesar Rp24.467.716/tahun, yang terdiri dari pengeluaran kebutuhan pangan sebesar Rp12.268.320,00/tahun (50,15 persen) dan pengeluaran non pangan sebesar Rp12.199.296,00/tahun (49,85 persen). Pengeluaran rumah tangga petani untuk kebutuhan pangan lebih besar dibandingkan untuk pengeluaran non pangan. Hasil ini menunjukkan bahwa rumah tangga petani lebih mengutamakan pemenuhan kebutuhan pangan.

Total pengeluaran rumah tangga kemudian dikonversikan kedalam ukuran setara beras per kilogram, untuk mengetahui tingkat kesejahteraan rumah tangga petani. Harga beras yang digunakan sebesar Rp11.640,00. Berdasarkan kriteria pengukuran yang telah ditetapkan oleh Sajogyo, pengeluaran rumah tangga perkapita per tahun rumah tangga petani ubi kayu di Kecamatan Natar berada diantara $481-960 \mathrm{~kg}$ nilai beras per tahun. Sehingga, sebesar 72 persen rumah tangga petani ubi kayu di Kecamatan Natar berada pada kategori cukup, sedangkan sebesar 18 persen berada pada kategori nyaris miskin, sebesar 8 persen berada pada kategori miskin dan sebesar 2 persen berada pada kategori hidup layak. 
Tabel 6. Rata-rata pengeluaran rumah tangga petani ubi kayu per tahun di Kecamatan Natar

\begin{tabular}{|c|c|c|}
\hline Kategori & $\mathrm{Rp}$ & Persentase \\
\hline \multicolumn{3}{|l|}{ Pangan } \\
\hline Pangan pokok & $428.740,00$ & 41,93 \\
\hline Umbi-umbian & $11.400,00$ & 1,11 \\
\hline Minyak dan lemak & $28.460,00$ & 2,78 \\
\hline Pangan hewani & $176.960,00$ & 17,30 \\
\hline Pangan nabati & $55.320,00$ & 5,41 \\
\hline Buah/biji berminyak & 0,00 & 0,00 \\
\hline Kacang-kacangan & 0,00 & 0,00 \\
\hline Gula & $21.320,00$ & 2,08 \\
\hline Sayuran & $64.490,00$ & 6,30 \\
\hline Sayur buah & $108.560,00$ & 10,61 \\
\hline Buah & $59.180,00$ & 5,78 \\
\hline Minuman & $42.500,00$ & 4,15 \\
\hline Lainnya & $25.430,00$ & 2,48 \\
\hline T. pngl pangan/bulan & $1.022 .360,00$ & 100,00 \\
\hline T.pngl pangan/tahun & $12.268 .320,00$ & 50,15 \\
\hline \multicolumn{3}{|l|}{ Non pangan } \\
\hline Kesehatan & $52.000,00$ & 5,11 \\
\hline Pendidikan & $238.752,00$ & 23,48 \\
\hline Listrik & $104.600,00$ & 10,28 \\
\hline Telp/HP & $37.560,00$ & 3,69 \\
\hline $\begin{array}{l}\text { Perbaikan dan perabotan } \\
\text { rumah }\end{array}$ & 0,00 & 0 \\
\hline Pakaian dan aksesoris & $33.312,00$ & 3,27 \\
\hline Barang dan jasa & $216.200,00$ & 21,26 \\
\hline Bahan bakar & $122.580,00$ & 12,05 \\
\hline Transportasi & $4.200,00$ & 0,41 \\
\hline Sosial & $72.600,00$ & 7,14 \\
\hline Pajak & $26.027,00$ & 2,56 \\
\hline Kebersihan badan & $65.350,00$ & 6,42 \\
\hline Kosmetik & $43.435,00$ & 4,27 \\
\hline T. pngl non pangan/bulan & $1.016 .616,00$ & 100,00 \\
\hline T. pngl non pangan/tahun & $12.199 .396,00$ & 49,85 \\
\hline Total seluruh Pengeluaran & $24.467 .716,00$ & 100,00 \\
\hline
\end{tabular}

\section{KESIMPULAN}

Dari penelitian ini disimpulkan bahwa usahatani ubi kayu di Kecamatan Natar terbilang layak dan menguntungkan karena memiliki nilai R/C lebih dari satu. Pendapatan rumah tangga petani paling besar diperoleh dari pendapatan on farm, yaitu usahatani ubi kayu sebesar 62,34 persen dan sisanya sebesar 37,66 persen berasal dari usaha lain. Berdasarkan pengukuran kesejahteraan menurut BPS 2014 sebesar 86 persen rumah tangga petani berada pada golongan sejahtera dan menurut Sajogyo (1997) sebesar 72 persen rumah tangga petani ubi kayu tergolong cukup.

\section{DAFTAR PUSTAKA}

Badan Pusat Statistik. 2014. Indikator Kesejahteraan Rakyat 2014. Badan Pusat Statistik. Jakarta.

Badan Pusat Statistik. 2016. Lampung Selatan Dalam Angka. Badan Pusat Statistik Provinsi Lampung. Bandar Lampung.

Badan Pusat Statistik. 2017. Lampung Dalam Angka. BPS Provinsi Lampung. Bandar Lampung.

Clinton, Ginting R, dan Jufri M. 2015. Analisis usahatani ubi kayu (manihot esculenta) studi kasus Desa Marihat Bandar, Kecamatan Bandar, Kabupaten Simalungun. Jurnal Pertanian.Universitas Sumatera Utara. Vol 4 (12):51-61. http://jurnal.usu.ac.id/index.php/ceress/arti cle/view/14442. [15 Juli 2018].

Gusti AI, Haryono D, dan Prasmatiwi FE. 2013. Pendapatan rumah tangga petani kakao di Desa Pesawaran Indah Kecamatan Padang Cermin Kabupaten Pesawaran. Jurnal Ilmu Ilmu Agribisnis. 1 (4):278-283. http://jurnal.fp.unila.ac.id/index. php/JIA/article/view/701. [15 Juli 2018].

Sajogyo. 1997. Garis Kemiskinan dan Kebutuhan Minimum Pangan. LPSB IPB. Bogor.

Saputra AARE, Wijaya S, dan Kalsum U. 2016. Pendapatan dan kesejahteraan anggota KSP Tani Makmur Kecamatan Natar Kabupaten Lampung Selatan. Jurnal Ilmu Ilmu Agribsnis. 4

(2):161-167. http://jurnal.fp.unila.ac.id/index.php/JIA/articl e/view/1233/1130. [20 Juni 2018].

Soekartawi. 2002. Analisis Usahatani. UI Press. Jakarta.

Sugiarto. 2003. Teknik Sampling. Gramedia. Jakarta

Sukirno. 2005. Pengantar Teori Mikro Ekonomi. PT Raja Grafindo Persada. Jakarta.

Puji PU, Gitosaputro S, dan Nikmatullah D. 2017. Pendapatan dan kesejahteraan petani jagung di Ketapang Kabupaten Lampung Selatan. Jurnal Ilmu Ilmu Agribisnis. 4 (3):25-27. http://jurnal.fp.unila.ac.id/

index.php/JIA/article/view/211. [15 Juli 2018]. 